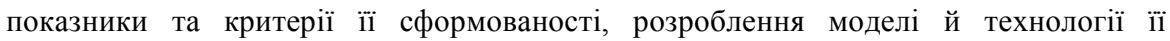
формування.

1. Блауберг И. В. Становление и сущность системного похода / И. В. Блауберг, Э. Г. Юдин. - М. : Наука, 1973. - 270 с. 2. Болотов В. А. Компетентностная модель: от идеи к образовательной парадигме / В. А. Болотов, В. В. Сериков // Педагогіка. $-\quad 2003 .-\quad$ №10. $-\quad$ С. $8-14 . \quad$ 3. Зеep Э. Ф. Компетентностный подход к образования [Електронний ресурс] / Э. Ф. Зеер.Режим доступу: http:/www.urorao.ru/ konf 2005 4. Зимняя И. А. Педагогическая психология / Ирина Алексеевна Зимняя. - Ростов-на-Дону : Феникс, 1997. - 480 с. 5. Сластенин В. А. Введение в педагогическую аксіологію : [учеб. пособие для студ. высш. пед. учеб. заведений] / В. А. Сластенин, Г. И. Чижакова. - М : Изд. центр «Академия», 2003. - 192 с. 6. Хомич Л. О. Професійно-педагогічна підготовка вчителя початкових класів / Лідія Олексіївна Хомич. - К. : Магістр-S, 1998. -201 c.

УДК 371.132

Ірина Максименко

\title{
ПРОФЕСІЙНО-ПЕДАГОГІЧНА СПРЯМОВАНІСТЬ ЯК ДЕТЕРМІНАНТА ПРОФЕСІЙНОГО СТАНОВЛЕННЯ МАЙБУТНЬОГО ІНЖЕНЕРА-ПЕДАГОГА
}

Максименко I. Г. Професійно-педагогічна спрямованість як детермінанта професійного становлення майбутнього інженера-педагога.

У статті розкрито сутність професійно-педагогічної спрямованості, охарактеризовано змістовий, мотиваційний та процесуальний компоненти структури, динаміка падіння індексу задоволеності професійним вибором, етапи особистісного зростання, критерії та рівні сформованості, висвітлено значущысть у професійного становлення майбутнього інженера-педагога.

Ключові слова: професійно-педагогічна спрямованість, професійне становлення, професійне самопізнання, самовизначення, самосвідомість.

Максименко И. Г. Профессионально-педагогическая направленность как детерминанта профессионального становления будущего инженера-педагога.

В статье раскрывается сущность профессионально-педагогической направленности, характеризуються содержательный, мотивационный, процессуальный компоненты еe структуры, динамика падення индекса удовлетворенности профессиональным выбором, этапы личностного роста, критерии, и уровни сформированности, освещается значимость профессионального становления будущего инженера-педагога.

Ключевые слова: профессионально-педагогическая направленность, профессиональное становление, профессиональное самопознание, самоопределение, самосознание.

Maksymenko I. G. Professional and pedagogical orientation as a determinant of becoming a professional engineer future teacher.

The article discloses the essence of professional pedagogical orientation, describes semantic, procedural and motivational components of its structure, dynamics of index's reduction in satisfaction of professional selection, stages of personal development, criteria 
and levels of development. The article covers the signification of professional development in the future of engineer-teache.

Key words: professional pedagogical orientation, professional development, professional self-determination, professional self-knowledge, professional selfactualization.

Гуманізація суспільства, нові вимоги до особистості потребують перегляду ролі педагога в освіті, оновлення змісту його підготовки. Теоретичний аналіз та аналіз практики дозволив виявити суперечності між ускладненим соціальним замовленням на підготовку інженера-педагога й усталеною практикою підготовки педагогів до професійної діяльності. Підвищення якості професійної підготовки майбутнього інженера-педагога суттєво залежить від обгрунтованого і свідомого вибору педагогічної професії випускниками загальноосвітніх шкіл. Від правильного професійного вибору залежить майбутнє особистості, іiі позитивне ставлення до обраного виду праці, усвідомлення себе як суб'єкта конкретної професійної діяльності, професійно-кваліфікаційне зростання.

Реалізація всіх аспектів освіти пов'язана 3 особистістю педагога, 3 необхідністю постійного вдосконалення й підвищення рівня професіоналізму у процесі професійного становлення. Теоретичний аналіз проблеми професійного становлення свідчить про те, що в дослідженнях науковців (Т. Балл, О. Головаха, Л. Захарова, Є. Климов, Г. Костюк, Т. Кудрявцев, Л. Мітіна, Н. Ничкало, В. Рибалко та ін.) акцентується ставиться на необхідності вивчення ролі суб'єкта окресленого процесу.

Ефективність професійного становлення майбутнього педагога значною мірою залежить від ставлення до педагогічної професії випускників загальноосвітніх шкіл. Найбільш узагальненою формою ставлення до свідомого й обгрунтованого професійного вибору є професійна спрямованість, яка визначається як інтерес до професії і схильність займатися нею (Н. Кузьміна).

Проблема професійно-педагогічної спрямованості $\epsilon$ предметом вивчення багатьох науковців. Зокрема, у дослідженнях С. Рубінштейна професійна спрямованість тлумачиться як виявлення загальної спрямованості у праці [7]. Л. Мітіна професійну спрямованість ототожнюється 3 професійними інтересами й намірами [4]. У психології феномен професійно-педагогічної спрямованості розуміють як систему особистісних якостей, які визначають стійке, усвідомлене, активно-дієве ставлення до педагогічної праці (С. Науменко); професійно значуща якість особистості вчителя (П. Фастовець); форма активності студентів (Л. Захарова).

Проте, проблема формування професійно-педагогічної спрямованості як важливий внутрішній чинник професійного становлення майбутнього інженерапедагога не знайшла належного розроблення у психолого-педагогічних дослідженнях, що визначає іiї актуальність.

Meта статmі полягає у висвітленні сутності професійно-педагогічної спрямованості, критеріїв і рівнів сформованості та визначення ролі у професійному становленні майбутніх інженерів-педагогів.

У науковій літературі професійне становлення визначається як процес, що відбувається шляхом якісних змін в особистісному розвитку, які впливають на основні життєві ставлення майбутніх інженерів-педагогів, Зміни відбуваються у свідомості, психічних процесах, світогляді, розвитку трудових умінь і навичок, що сприяє формуванню професіоналізму. 
Оптимальний особистісний розвиток здійснюється у процесі успішного оволодіння професійною діяльністю. Адже, чим вищі досягнення професійного становлення, сприяють розвитку особистості. Для педагогічної діяльності це має надзвичайно велике значення, оскільки «робочим інструментом» педагога є його власна особистість. Саме тому в педагогічній професії особистісне зростання $\epsilon$ обов'язковою умовою досягнення професіоналізму, що виражається у прагненні ставати все більш компетентним і здібним настільки, наскільки це можливо біологічно (К Роджерс).

Професійне становлення $€$ достатньо складним, тривалим, мобільним, багатоплановим, зокрема суперечливим процесом, у якому виокремлюють довишівський, вишівський, післявишівський етапи.

Довишівський етап професійного становлення пов'язаний із підготовкою учнів до вибору педагогічної професії. Цей етап грунтується на врахуванні інтересів педагогічної діяльності, професійно-педагогічної придатності (відповідності індивідуально-психологічних особливостей вимогам професіі). Наявність інтересу і здібностей до обраної професії сприятиме в подальшому успішному оволодінні нею, загалом - професійному зростанню у процесі педагогічної діяльності.

Вишівський етап пов'язаний з отриманням професії в навчальному закладі. Післявишівський етап професійного становлення педагога відбувається у процесі безпосередньої професійної діяльності в закладах освіти. Одним із напрямків підвищення ефективності професійного становлення $є$ формування у майбутніх інженерів-педагогів професійно-педагогічної спрямованості.

Професійно-педагогічна спрямованість виявляється на довишівському етапі у процесі вибору професії. Правильний вибір професії ототожнюється 3 поняттям «професійне самовизначення», яке полягає у трансформації соціально значчущих професійних цінностей в особистісну цінність. Від правильного професійного самовизначення залежить майбутнє особистості, іiї ставлення до праці, професійнокваліфікаційне зростання, задоволення професійною діяльністю.

Проблема професійного становлення посідає важливе місце у психологопедагогічній літературі, оскільки передбачає визначення в життєвій самореалізації особистості. Аналіз досліджень (Е. Головаха, С. Гончаренко, Н. Кузьміна, Е. Науменко, Н. Пилипенко та ін.) свідчить, що професійне самовизначення розглядається як вибір професії з кількох можливих варіантів через самопізнання й об'єктивне оцінювання своїх індивідуальних особливостей 3 орієнтацією на співвідношення власних можливостей із вимогами професії. Проблема професійного самовизначення досліджувалася в контексті особистісного самовизначення: самопізнання, визначення свого місця у світі, аналізом особистісних ресурсів, співвіднесенням із професійними вимогами. У процесі професійного самовизначення людина враховує, по-перше сукупність об'єктивних умов (наявність навчальних закладів, потреби регіону в професії тощо), по-друге, власні цінності, інтереси, потреби, пов'язані 3 майбутньою педагогічною діяльністю.

Свободу професійного вибору певним чином обмежують об'єктивні чинники, пов'язані, по-перше, з прагненням випускників шкіл обрати професію, яка, на їх думку, повинна забезпечити гідне місце для реалізації власних сил, та неможливістю системи освіти в забезпеченні в повному обсязі кількості вакантних місць у ВНЗ; по-друге, з орієнтованістю професійних планів молоді на престижні професії, до яких нині не можна віднести педагогічну. Крім того, зовнішнє середовище (школа, сім'я, засоби масової інформації тощо) не є референтною 
основою прийняття свідомого рішення щодо вибору професії. Суб'єктивні обмеження пов'язані передовсім із професійною мотивацією, наявністю педагогічних здібностей і професійно значущих особистісних якостей, необхідних для ефективної майбутньої професійно-педагогічної діяльності.

3 огляду на вищеокреслене процес правильного вибору професії передбачає активну позицію у виборі тих видів діяльності, що максимально відповідають індивідуальним здібностям особистості й потребам суспільства.

Результатом відсутності такої відповідності $\epsilon$ наявність непоодиноких випадків розчарування студентів своїм професійним вибором і намагання змінити навчальний заклад або спеціальність. Проведене дослідження є свідченням того, що якщо 3-поміж першокурсників 56\% студентів приваблювала перспектива стати інженером-педагогом, то на кінець першого курсу кількість студентів, що виявили задоволення обраною професією різко зменшилася (до 31,2\%).

Зміна ставлення студентів до обраної професії пов'язана 3 тим, що у випускників загальноосвітніх шкіл не завершився процес професійного самовизначення. Зміст професії, процес оволодіння нею відкривається їм новими сторонами, до сприйняття яких студенти були не готові. За період навчання у ВНЗ суттєвих змін у формуванні професійного самовизначення не прослідковується, про що свідчить зниження індексу задоволення майбутньою професійною діяльністю.

Аналіз отриманих експериментальних даних дає підстави констатувати динаміку падіння індексу задоволення професією: за максимального індексу задоволення абітурієнтів і студентів в 3 бали (за роками навчання становить відповідно 1,$84 ; 1,71 ; 1,64 ; 1,62 ; 1,58)$.

Пошук причин досліджуваного явища засвідчив, що починаючи 31 -го курсу поступове зменшення задоволення майбутньою професійною діяльністю пов'язане 3 розширенням знань щодо змісту і специфіки професії, сприймати, які студенти не готові; зниженням впевненості відповідно до власних здібностей вимогам майбутньої професійної діяльності; усвідомленням зовнішніх негативних чинників професії (ненормований робочий день, велике емоційне навантаження, низька заробітна платня, високий рівень відповідальності тощо), недостатньою сформованістю необхідних особистісних якостей i невідповідністю здібностей вимогам професійно-педагогічної діяльності.

Вищезазначене актуалізує необхідність формування професійно-педагогічної спрямованості у майбутніх інженерів-педагогів на етапі оволодіння професією в навчальному процесі вищої школи.

Професійно-педагогічна спрямованість - це професійно-значуща риса, яка в структурі особистості педагога посідає центральне місце і зумовлює своєрідність діяльності [7]. У дослідженні Л. Мітіної професійно-педагогічну спрямованість подано як багатосистемне утворення, яке становить ціннісні орієнтаціі); на мету педагогічної діяльності [7, с. 38-41].

Феномен професійно-педагогічної спрямованості психологи розглядають як систему особистісних якостей, які визначають стійке, усвідомлене, активно-дієве ставлення до педагогічної праці [1], як професійно значущу якість особистості вчителя, основним мотивом якої $є$ спрямованість на розвиток особистості учня (гуманістичний мотив); яка залежить від характеру провідного мотиву в структурі мотивації вчителя [6], як розуміння і внутрішнє прийняття мети й завдань професійної діяльності, ㄲï інтересів, ідеалів, настанов, переконань, поглядів, що характеризуються «стійкістю (нестійкістю), домінуванням суспільних або вузькоособистісних мотивів, далекою або близькою перспективою» [5]. 
Вважаємо, під педагогічною спрямованістю варто розуміти мотиви, інтерес до педагогічної професії, спроможність і потребу педагогічної діяльності.

На основі аналізу психолого-педагогічної літератури у структурі професійнопедагогічної спрямованості особистості майбутнього інженера-педагога можна виокремити три компоненти: змістовий (інформованість щодо сутності й особливостей інженерно-педагогічної діяльності, знання особистісних професійно важливих якостей), мотиваційний (потреби, інтереси, ціннісні орієнтації царини професійної діяльності), процесуальний (готовність до оволодіння професією).

Виходячи із визначення професійно-педагогічної спрямованості в нами виокремлено як критерії іï сформованості: інтерес до професії учителя, особистісне ставлення до педагогічної діяльності; усвідомлення студентами сутності та специфіки педагогічної професії; готовність до роботи в закладах освіти. Кожному 3 компонентів притаманна множинність конкретних проявів, які свідчать про рівень сформованості як кожного з них, зокрема, так і сформованості професійнопедагогічної спрямованості як комплексної властивості. Відповідно, до критеріїв умовно виокремлено три рівні сформованості професійно-педагогічної спрямованості студентів: достатньо виражена, виражена, недостатньо виражена спрямованість.

Студенти 3 достатньо вираженою спрямованістю мають стійкий інтерес до професії інженера-педагога, глибокі знання щодо специфіки інженерно-педагогічної діяльності. Їхні життєві плани пов'язані $з$ перспективою оволодіння професією, а тому вони виявляють морально-вольову готовність до викладацької діяльності.

Студенти з частково визначеною спрямованістю характеризуються не стійким інтересом, не глибокими знаннями сутності педагогічної діяльності. Їх приваблює зовнішній аспект педагогічної діяльності. До роботи в навчальних закладах не виявляють позитивного ставлення.

У студентів з невираженою спрямованістю відсутній інтерес до педагогічної професії, знання в галузі педагогічної діяльності поверхові, мають емпіричний характер. Своє майбутнє з педагогічною діяльністю не пов'язують.

Узагальнені результати проведеного дослідження дають підстави задля висновку: виражена спрямованість характеризує кожного третього студента $(29,7 \%)$, а майже половина $(48,4 \%)$ студентів володіють невираженою спрямованістю на педагогічну професію. Задля вдосконалення професійного становлення необхідно, щоб студент усвідомлював себе суб'єктом професійного вибору, здатний до визначення й реалізації цілей саморозвитку, оволодівав професійними знаннями та вміннями, усвідомлював труднощі майбутньої професійної діяльності.

Отже, професійно-педагогічна спрямованість визначається як узагальнена форма ставлення до професії, яка передбачає професійний інтерес як безпосереднє, емоційне, практично-пізнавальне ставлення до професії, бажання отримати якомога більше інформації щодо ii змісту і специфіки, професійно важливих якостей особистості вчителя, готовність до педагогічної діяльності.

Проведене дослідження актуалізує проблему i доводить необхідність формування професійно-педагогічної спрямованості у студентів як одного із провідних напрямів ефективності професійного становлення.

\section{Література}

1. Головаха Е. И. Жизненная перспектива и профессиональное самоопределение молодежи / Е. И. Головаха. - М. : Просвещение, 1998. - С. 96-98. 2. Захарова Л. Н. Личностные особенности, стили поведения и типы 
профессиональной самоиндетификации у студентов педвуза / Л. Н. Захарова // Вопросы психологии. -1991. - № 2. - С. 16. 3. Кузьмина Н. В. Профессионализм личности преподавателя и мастера производственного обучения / Н. В. Кузьмина. М. : Просвещение, 1990. - С. 312. 4. Митина Л. М. Психология профессионального развития / Л. М. Митина. - М. : Флинта, 1998. - С. 38-41. 5. Науменко Е. А. Психологическая структура и формирование профессионально-педагогической направленности личности: автореф. дис. ... канд. псих. наук: спец. 19.00.01/ Е. А. Науменко. - М., 1987. - 22 с. 6. Пилипенко Н. В. Вплив кризи професійного становлення на саморозвиток особистості / Н. М. Пилипенко // Педагогіка i психологія. - 2005. - № 2. - С. 117-118. 7. Рубинштейн С. Л. Проблемы общей психологи / С. Л. Рубинштейн. - M. : Просвещение, 1976. - С. 415. 8. Фастовец П. В. Формирование профессионально-педагогической направленности личности учителя : автореф. дис. ... канд. псих. наук : спец. 19.00.01 / Фастовец П. В. - М. , 1998. - 20 с.

Наталя Мозгальова

\section{КОНЦЕПТУАЛЬНІ ПІДХОДИ ДО ОНОВЛЕННЯ ЗМІСТУ ІНСТРУМЕНТАЛЬНО-ВИКОНАВСЬКОЇ ПІДГОТОВКИ ВЧИТЕЛІВ МУЗИКИ}

Мозгальова Н. Г. Концептуальні підходи до оновлення змісту інструментальновиконавської підготовки вчителів музики.

У статті запропоновано концептуальні засади інструментально-виконавської підготовки вчителів музики. Теоретично обгрунтовано сутність і специфіку таксономічного підходу в галузі інструментального виконавства. Визначено мету, завдання, принципи навчання в інструментальному класі. Наголошено, що підвищення якості інструментально-виконавської підготовки можливе, якщо перетворити процес навчання гри на музичних інструментах на організаційнометодичну систему, розроблення якої необхідно здійснювати 3 урахуванням визначених ідей.

Ключеві слова: концептуальні засади, інструментально-виконавська підготовка, вчитель музики, цілі, таксономічний підхід.

Мозгалева Н. Г. Концептуальные подходы к обновлению содержания инструментально-исполнительской подготовки учителей музыки.

В статье обосновываются концептуальные основы инструментальноисполнительской подготовки учителей музыки. Теоретически обосновано сущность и специфика таксономического подхода в области инструментального исполнительства. Определены цели, задачи, принципы обучения в фортепианном классе. Отмечено, что повышение качества инструментально-исполнительской подготовки возможно, если представить процесс обучения игры на музыкальных инструментах как организационно-методическую систему, моделирование которой необходимо осуществлять с учетом определенных идей.

Ключевые слова: концептуальные основы, инструментально-исполнительское подготовка, учитель музыки, цели, таксономический подход.

Mozgaleva N. G. Conceptual approaches to update the content of instrumental music teachers pidgotovki executive. 